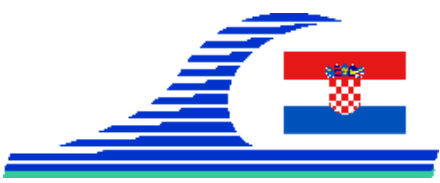

\title{
Sand beaches of the SE Adriatic: insights from sediment composition
}

\author{
Borna LUŽAR-OBERITER ${ }^{1}$, Ljubomir BABIĆ ${ }^{1}$, Ivan RAZUM ${ }^{2}$, Jožica ZUPANIČ ${ }^{1}$
}

1. Department of Geology, Faculty of Science, University of Zagreb, Horvatovac 102a, 10000 Zagreb, Croatia.

bluzar@geol.pmf.hr

2. Croatian Natural History Museum, Demetrova 1, 10000 Zagreb, Croatia.

\begin{abstract}
:
Sand beaches of the Eastern Adriatic Croatian coast present an important natural and economic resource, which is under increasing pressure from development. The composition of sand from 13 pocket beaches of SE Adriatic islands and neighbouring Pelješac Peninsula, as well as of potential source rocks, was studied in order to improve our understanding of natural supply processes. Heavy mineral associations suggest that patchy occurrences of Pleistocene sands overlying the carbonate basement represent the dominant source. Special care should be dedicated to the protection of these sources and transport paths.
\end{abstract}

Keywords: Sand, Beaches, Eastern Adriatic, Heavy minerals, Sediment sources, Protection.

\section{Introduction}

As pressure from development on coastal environments constantly intensifies, efforts for coastal conservation must be continuously reinforced. A large part of the world's coastlines, i.e. about $40 \%$, are occupied by sand and gravel beaches which are known to be a diminishing resource (BIRD, 1996; BEATLEY et al., 2002). Eastern Adriatic beaches of the Croatian coast are an important resource for the country as they represent highly valuable landscapes and important natural heritage, recreational and tourism areas, yet poor knowledge of these natural environments makes them specifically vulnerable (CRNJAKOVIĆ et al., 1998; PAVIČIĆ et al., 2000; LUŽAR-OBERITER, 2006; LUŽAR-OBERITER et al., 2008). If the beaches are to be used and enjoyed in the future, our understanding of the features and processes characterising and sustaining these environments must be improved.

This contribution results from a study of 13 sand beaches of the SE Adriatic (figure 1). It presents the results obtained from the investigation of beach sand composition, as well as the composition of rocks exposed in the same area, which represent potential sources of sand detritus. The aim of the study was to relate data obtained from the 
Mediterranean rocky coasts:

Features, processes, evolution and problems

beaches and sediment sources in order to better understand natural supply processes and to be able to protect and sustain them in the future. The definition of protection measures based on geological data is of immense importance as (1) the number of sand beaches along the relevant coasts is small, (2) the beaches are of small dimensions and (3) there is a trend to enlarge and modify sand beaches into gravel beaches or to replace them by artificial terraces. Therefore, there is an increasing danger of losing the remaining natural sand beaches and it is the last moment to stop their modification.

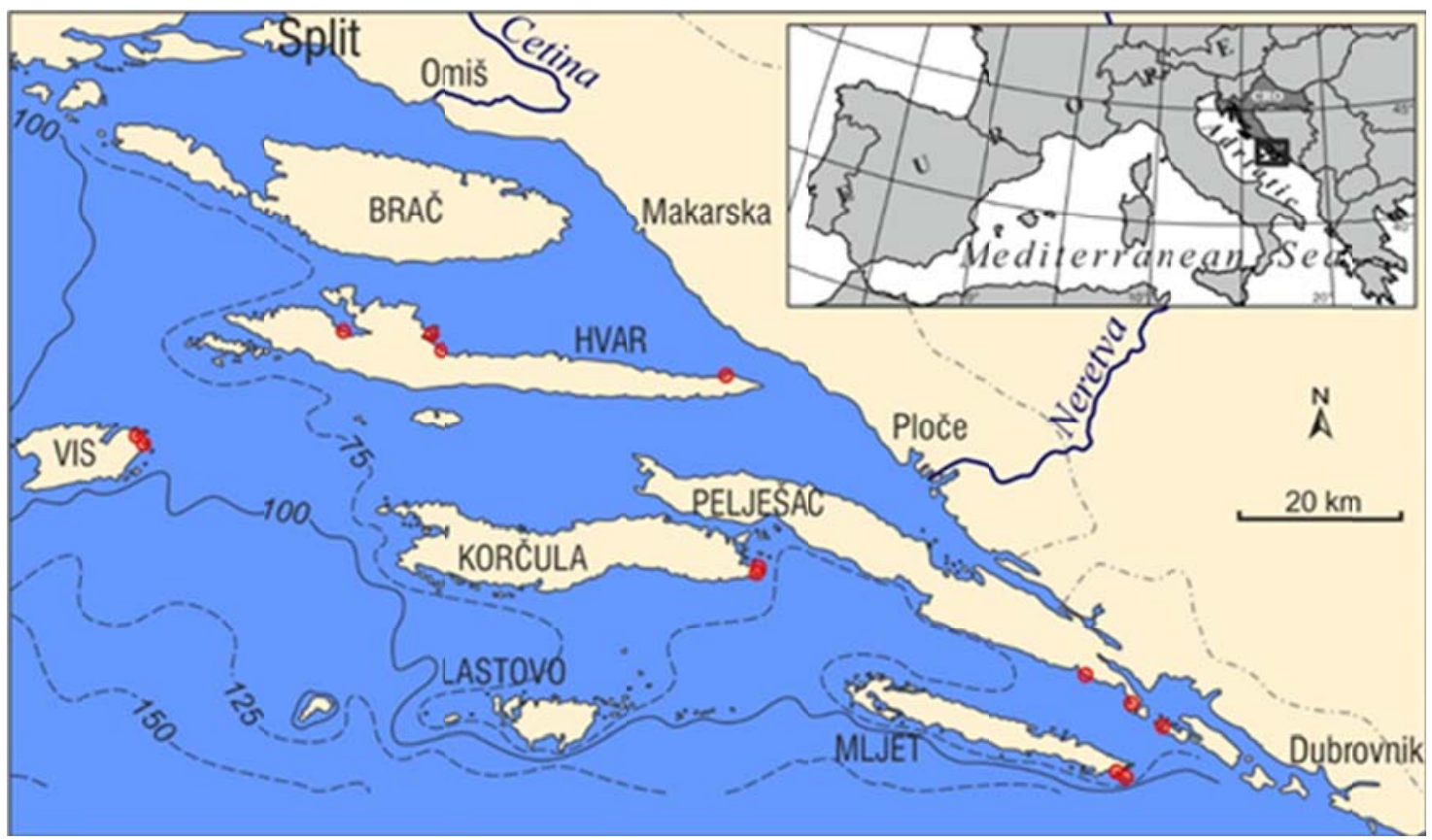

Figure 1. Locations of the studied sand beaches of the SE Adriatic.

\section{Materials and methods}

The studied beaches are mostly located along the coasts of the islands of the SE Adriatic Sea, including the islands of Vis, Hvar, Korčula, Mljet and Jakljan, with a few of beaches occurring on the Pelješac Peninsula. The relevant coasts are well indented, displaying numerous, small bays and headlands. As a rule, sand beaches occur at the head of bays, while the bay flanks and headlands consist of relatively resistant carbonate rocks, limestones and dolomites. Rippled sands cover the shallow bottom in front of the beaches. Aside from widespread carbonate rocks, the geology of the study area consists of additional rock units which have been tested as to identify source areas of the beach sand detritus. One of them is represented by Pleistocene sands and the other one by Palaeogene clastics. The first one occurs as patchy fields overlying the carbonate basement. The second is foreland basin flysch sediments consisting predominantly of marl, sandstones, calcarenites, carbonate breccias and conglomerates. 
Mediterranean rocky coasts:

Features, processes, evolution and problems

Two methods were used to test the compositional similarity between beach sands and possible sources. Petrographic analysis was performed on thin sections using a polarizing microscope, which provided data on the main constituent particles. The other method used was the analysis of heavy mineral associations which include mineral species usually present in concentrations of less than $1 \%$, however, they are useful as identifiers of specific source rock types from which the minerals derived.

\section{Results}

Although both methods provided useful insights, the second one, heavy mineral analysis proved particularly indicative. Heavy mineral associations of beach sands and of Pleistocene sands closely resemble one another. Associations from these sample groups are highly dominated by three mineral groups: clinopyroxenes, orthopyroxenes and amphiboles. In contrast, heavy mineral associations from Palaeogene clastic sediments occurring within the study area show pronounced differences. Namely, Palaeogene samples contain a considerable, and in the same time, variable proportion of garnet, largely variable proportion of amphiboles (negligible to high) and a small to high proportion of ultrastable minerals (zircon, trourmaline, rutile), while pyroxenes are poorly represented. These results clearly indicate that Pleistocene sands represent the main source for the studied beach sands, the material being delivered partly by surface run-off and partly by direct marine erosion of Pleistocene sediments backing the beaches. The possible contribution from sands covering the sea bottom in front of the beaches requires further study. The pronounced difference between heavy mineral associations of beach sands and Palaeogene clastics may be interpreted as resulting due to the large distance between Palaeogene rocks and beaches, as well as the presence of topographic barriers.

\section{Conclusions}

The results of this study show that the applied methods are useful for planning protection measures related to beach preservation. The presented data suggest that the most important measure is the protection of sediment source areas and transport paths leading from the sources to the beaches. In some of the studied beaches this may be inferred from accurate field observations. In other cases, however, the precise distribution of Pleistocene sources of detritus is not easily observed. Here relevant transport paths seem to be more complex and may have already been interrupted. These latter cases require detailed studies of extended areas surrounding the beaches.

\section{References}

BIRD E. C. F. (1996). Beach Management. Chichester, New York, John Wiley, 281 p. ISBN 0471963372 
Mediterranean rocky coasts:

Features, processes, evolution and problems

BEATLEY T., BROWER D. J., SCHWAB A. K. (2002). An introduction to coastal zone management. $2^{\text {nd }}$ Edition, Island Press, Washington, $329 \mathrm{p}$.

CRNJAKOVIĆ M., BABIĆ L. J., ZUPANIČ J. (1998). Sustainibility of beaches of the Croatian Adriatic coast: a sediment source perspective. in Croatian, English abstract, in Arko-Pijevac, M., Kovačić M., Crnković D. (Editors), Prirodoslovna istraživanja riječkog područja. Prirodoslovni muzej, Rijeka, pp. 339-344.

LUŽAR-OBERITER B. (2006). A comparison of the composition and sources of coastal sands from the Islands of Hvar and Rab. in Croatian, English abstract. Master Thesis, Faculty of Science, University of Zagreb, Zagreb, 85 p.

LUŽAR-OBERITER B., MIKULČIĆ-PAVLAKOVIĆ S., CRNJAKOVIĆ M., BABIĆ L. J. (2008). Variable sources of beach sands of north Adriatic islands: examples from Rab and Susak. Geologia Croatica, Vol. 61 (2-3), pp. 379-384.

PAVIČIĆ L. J., BABIĆ L. J., CRNJAKOVIĆ M., ZUPANIČ J. (2000). The provenance of sands on North Dalmatian beaches: between ignorance and the need for coastal zone management. Periodicum Biologorum 102, Supplement 1, Zagreb, pp. 349-354. 